\title{
Evaluation of the entomopathogenic fungi as a non-traditional control of the rice leaf roller, Cnaphalocrocis medinalis (Guenee) (Lepidoptera: Pyralidae) under controlled conditions
}

\author{
Muhammad Rizwan ${ }^{1 *}$, Bilal Atta ${ }^{1}$, Arshed Makhdoom Sabir ${ }^{1}$, Misbah Yaqub ${ }^{2}$ and Abdul Qadir $^{3}$
}

\begin{abstract}
The rice leaf roller or leaf folder, Cnaphalocrocis medinalis (Guenee) (Lepidoptera: Pyralidae), is a serious pest of rice crop in Pakistan. The present study was carried out to evaluate the virulence of the entomopathogenic fungi (EPF) Beauveria bassiana, Verticillium lecanii, and Metarhizium anisopliae against the third instar of C. medinalis larvae. Larvae were exposed to fungi under controlled conditions at the available commercial concentration $\left(1 \times 10^{8}\right.$ conidia $\mathrm{ml}^{-1}$ ). The results showed $73.33,57.78$, and $74.44 \%$ mortality rates in the in vitro assay and $56.67,41.11$ and $52.78 \%$ in the greenhouse assay of B. bassiana, V. lecanii, and M. anisopliae, respectively. The maximum mycosis from cadavers of $C$. medinalis was observed at B. bassiana treatment in the in vitro assay (70\%) and in the greenhouse assay (53.78\%). The maximum sporulation from C. medinalis cadavers was observed at B. bassiana treatment in the in vitro assay $\left(144.67\right.$ conidia $\mathrm{ml}^{-1}$ ) and in greenhouse assay $\left(96.67\right.$ conidia $\left.\mathrm{ml}^{-1}\right)$. These results favor the alternative use of EPF in organic rice production for management of $C$. medinalis.
\end{abstract}

Keywords: Cnaphalocrocis medinalis, Entomopathogenic fungi, In vitro assay, Greenhouse assay, Virulence

\section{Background}

Rice, Oryza sativa L., is the second cash crop of Pakistan after cotton. It also ranks second after wheat in cereals in terms of area and plays a significant role in the economy of Pakistan (Sherawat et al. 2007). In Pakistan, the rice stem borers, rice plant hoppers, rice leaf rollers, and grasshoppers are key pests of the rice crop (Saleem et al. 2004). The rice leaf roller, Cnaphalocrocis medinalis (Guenee) (Lepidoptera: Pyralidae), gained the status of a major pest that may cause $30-40 \%$ leaf infestation and $20-30 \%$ yield losses to the rice crop (Haider et al. 2014 and Prakash et al. 2008).

There are effective insecticides available to cope with this pest, but this solution is not a long-term strategy because of apprehensions about health and environmental hazards, exposure risks, residual perseverance, and development of resistance (Natarajan and Ramaraju 1997). Therefore, in recent years, the focus has been shifted towards biological control. Earlier researches suggested the possibility of the successful use of entomopathogenic fungi (EPF) such as Beauveria bassiana (Sivasundaram et al. 2007 and Ullah et al. 2018). EPF such as Metarhizium anisopliae and B. bassiana have been effectively used for biological control of aphids, lepidopteran caterpillars, and other pests. These fungicides are valued tools for non-chemical pest management strategies. M. anisopliae and B. bassiana are active agents against different stages of insect pests (Sivasundaram et al. 2007).

This study was carried out to evaluate the efficacy of EPF against $C$. medinalis for possible use in an organic rice production.

* Correspondence: ranarizwanjabbar@yahoo.com

${ }^{1}$ Rice Research Institute, Kala Shah Kaku, Punjab, Pakistan

Full list of author information is available at the end of the article 


\section{Materials and methods}

\section{Plant material and $C$. medinalis mass rearing}

Fine rice Basmati-515 variety was used for the evaluation of EPF against $C$. medinalis at $28 \pm 2{ }^{\circ} \mathrm{C}$ and $65 \pm 5 \% \mathrm{RH}$, at the Rice Research Institute, Kala Shah Kaku, Punjab, Pakistan, during the year 2018. Larvae of C. medinalis were collected from grown rice plants in nursery trays, seedlings were transferred from the nursery after 40 days to pots $(30 \mathrm{~cm}$ height and $9 \mathrm{~cm}$ diameter). Stock culture of the insect was maintained, following the method of Fujiyoshi et al. (1980), by releasing the newly emerged adults in ovipositional cages $(120 \times 80 \times 50 \mathrm{~cm})$. Moths were provided with a $10 \%$ honey solution as food and left for mating and egg laying. Ovipositional cages were observed daily till the hatched larvae reached the third instar (slightly dark green in color and a brownish patch on either side of pronotum) and then chosen for the bioassay tests. For the bioassay test, the third instar larvae were kept unfed for $3 \mathrm{~h}$ before each test, then transferred into Petri dishes, containing moistened filter paper at their bottom, to maintain the freshness and turgidity of clipped leaves.

\section{Entomopathogenic fungi}

Three fungi, B. bassiana, V. lecanii, and M. anisopliae, in talc forms, were obtained from AgriLife SOM Phytopharma (India) Limited (www.agrilife.in). All fungi were tested against $C$. medinalis, at a feasible conidial concentration $\left(1 \times 10^{8} \mathrm{CFU} / \mathrm{ml}\right)$ (Dal Bello et al. 2018). The quality of the treatments was checked by a heamocytometer. Potato dextrose agar (PDA) was used to determine the conidial germination. The conidial germination was measured, based on the counts of 200 random conidia per plate, $18 \mathrm{~h}$ post-incubation at $25 \pm 2{ }^{\circ} \mathrm{C}$ (Ayala-Zermeňo et al. 2015).

\section{Fungal pathogenicity against $C$. medinalis larvae In vitro assay}

Available concentration $\left[1 \times 10^{8}\right.$ colony-forming unit/ gram $(\mathrm{CFU} / \mathrm{g})]$ of fungi was used in the laboratory in order to study the pathogenicity of the tested fungi against the third instar larvae of $C$. medinalis. Twenty larvae were used in each replication. The tested larvae were collected from the potted plants in vials, starved for $3 \mathrm{~h}$, then dipped in each tested fungi solution at the chosen concentration for $10 \mathrm{~s}$, as described by Negasi et al. (1998). Sterilized distilled water was used as a control treatment. Mortality counts of the larvae were recorded for 10 days (Riasat et al. 2011).

\section{Greenhouse assay}

A rice nursery was grown in plastic trays with 60 plugs in each. The nursery was transplanted in a greenhouse after 30 days. Four plants were grown at $(22.5 \mathrm{~cm}$ row $\times$ row and plant $\times$ plant distance) and considered for each treatment replication. At the age of 60 days, the plants were sprayed by the help of a Pump Pressure Sprayer (Hommold, Lahore) with the fungal talc formulation. The third instar of $C$. medinalis larvae were collected, kept starved for $3 \mathrm{~h}$, and then shifted on the treated rice plants. Three replications, of 12 larvae, were used in each case. The mortality rate of the larvae was recorded after 10 days. The cadavers of $C$. medinalis were used to record the mycosis percentage. The cadavers were collected and preserved in sterile Petri plates. The cadavers were washed three times in sterile distilled water, and then the surface was sterilized for $2-3 \mathrm{~min}$ by a $0.05 \%$ sodium hypochlorite solution. Then, these cadavers were placed on Sabouraud dextrose agar (SDA) plates and incubated at $25 \pm 2{ }^{\circ} \mathrm{C}, 75 \pm 5 \mathrm{RH}$ for 7 days to observe the external white fungal growth under a stereomicroscope (Cole-Parmer 625 East Bunker Court Vernon Hills, IL, 60061, USA) (Riasat et al. 2011). Sporulation data were determined by mixing mycosed cadavers from each replicate in a beaker with a drop of Tween 80 with $20 \mathrm{ml}$ of distilled water (Tefera and Pringle 2003). Treatments were replicated three times independently. The solution was carefully stirred and the number of conidia was counted by using a hemocytometer under the microscope (Riasat et al. 2011).

\section{Statistical analysis}

All statistical analyses were conducted using Statistix software (version 8.1) (Tallahassee, FL). One-way ANOVA was applied in CRD to understand the mortality of $C$. medinalis and mycosis and sporulation from cadavers of tested EPF in in vitro and greenhouse assays. The means were separated, using the Tukey's HSD test at $P=0.05$.

\section{Results and discussion}

The pathogenicity of EPF, as a percent mortality $(F=94.3$, $\mathrm{DF}=3 / 11)$, percent mycosis $(F=633, \mathrm{DF}=3 / 11)$, and sporulation $(F=426, \mathrm{DF}=3 / 11)$, was highly significant $(P<0.01)$ in the in vitro assay, as well as in the greenhouse assay, where the percent mortality $(F=312, \mathrm{DF}=3$ / $11)$, percent mycosis $(F=469, \mathrm{DF}=3 / 11)$, and sporulation $(F=148, \mathrm{DF}=3 / 11)$ were recorded.

In the in vitro assay, the maximum percent mortality of C. medinalis $(74.44 \pm 4.44 \%)$ was observed by $M$. anisopliae, while the minimum $(57.78 \pm 5.30 \%)$ was recorded in $V$. lecanii. The highest percent of mycosis from $C$. medinalis cadavers $(70.00 \pm 1.53 \%)$ was observed at $B$. bassiana treatment, while the lowest $(61.33 \pm$ $1.76 \%)$ was recorded in $M$. anisopliae. Also, the maximum sporulation from $C$. medinalis cadavers (144.67 \pm 4.06 conidia $\mathrm{ml}^{-1}$ ) was observed at $B$. bassiana treatment, while the minimum $\left(133.33 \pm 3.28\right.$ conidia $\left.\mathrm{ml}^{-1}\right)$ was recorded in $M$. anisopliae (Table 1). 
Table 1 Percentage mortality of the third instar of Cnaphalocrosis medinalis larvae and percentage of mycosis and sporulation from their cadavers assayed with the entomopathogenic fungi, Beauvaria bessiana, Verticelium lecanii, and Metarhizium anisopliae in in vitro

\begin{tabular}{llll}
\hline Entomopathogenic fungi & Percent mortality & Percent mycosis & Sporulation $\left(\right.$ conidia ml $^{-1}$ ) \\
\hline Beauveria bassiana & $73.33 \pm 0.96 \mathrm{ab}$ & $70.00 \pm 1.53 \mathrm{a}$ & $144.67 \pm 4.06 \mathrm{a}$ \\
Verticillium lecanii & $57.78 \pm 5.30 \mathrm{~b}$ & $65.67 \pm 1.20 \mathrm{ab}$ & $122.33 \pm 3.48 \mathrm{~b}$ \\
Metarhizium anisopliae & $74.44 \pm 4.44 \mathrm{a}$ & $61.33 \pm 1.76 \mathrm{~b}$ & $113.33 \pm 3.28 \mathrm{~b}$ \\
Control & $2.22 \pm 0.56 \mathrm{c}$ & $0.00 \pm 0.00 \mathrm{c}$ & $0.00 \pm 0.00 \mathrm{c}$ \\
\hline
\end{tabular}

Means with different lowercase letters are significantly different (Tukey HSD at $P=0.05$ )

In the greenhouse assay, the maximum percent mortality of C. medinalis $(56.67 \pm 1.67 \%)$ was observed at $B$. bassiana treatment, while the minimum $(41.11 \pm 1.47 \%)$ was recorded in $V$. lecanii. the maximum percent mycosis from cadavers of $C$. medinalis $(53.78 \pm 0.87 \%)$ was showed at B. bassiana treatment, while the minimum $(39.78 \pm 1.56 \%)$ was recorded in $V$. lecanii. The highest sporulation from $C$. medinalis cadavers $(96.67 \pm 4.26$ conidia $\mathrm{ml}^{-1}$ ) was observed at $B$. bassiana treatment, while the lowest $\left(68.33 \pm 2.85\right.$ conidia ml $\left.{ }^{-1}\right)$ was recorded by $V$. lecanii (Table 2).

There was a clear percent mean mortality difference between in vitro and greenhouse assays. It could be due to continuous favorable and controlled conditions for fungal activity and pathogenicity in the case of the in vitro assay than in the greenhouse. Moreover, the larvae of $C$. medinalis were directly dipped in an EPF solution in the in vitro assay, while they were just released on sprayed plants in the case of the greenhouse assay.

Obtained data showed that microbial insecticides have shown promising results against $C$. medinalis larvae even the less percent mortality under greenhouse conditions is still satisfactory. Present data is in accordance with the findings of Alice et al. (2003) and Ambethgar et al. (2007) who reported that the B. bassiana was the most efficient for biological control of $C$. naphalocrocis under controlled conditions. Padmaja and Kaur (2001) and Ambethgar (2003) also recorded successful trials using $B$. bassiana against $C$. medinalis larvae.

Table 2 Percentage mortality of the third instar of Cnaphalocrosis medinalis larvae and percentage of mycosis and sporulation from their cadavers assayed with the entomopathogenic fungi, Beauvaria bessiana, Verticelium lecanii, and Metarhizium anisopliae in a greenhouse

\begin{tabular}{llll}
\hline $\begin{array}{l}\text { Entomopathogenic } \\
\text { fungi }\end{array}$ & $\begin{array}{l}\text { Percent } \\
\text { mortality }\end{array}$ & $\begin{array}{l}\text { Percent } \\
\text { mycosis }\end{array}$ & $\begin{array}{l}\text { Sporulation } \\
(\text { conidia ml }\end{array}$ \\
\hline Beauveria bassiana & $56.67 \pm 1.67 \mathrm{a}$ & $53.78 \pm 0.87 \mathrm{a}$ & $96.67 \pm 4.26 \mathrm{a}$ \\
Verticillium lecanii & $41.11 \pm 1.47 \mathrm{~b}$ & $39.78 \pm 1.56 \mathrm{~b}$ & $84.67 \pm 2.85 \mathrm{a}$ \\
Metarhizium anisopliae & $52.78 \pm 1.11 \mathrm{a}$ & $43.56 \pm 1.25 \mathrm{~b}$ & $68.33 \pm 4.91 \mathrm{~b}$ \\
Control & $7.22 \pm 0.56 \mathrm{c}$ & $0.00 \pm 0.00 \mathrm{c}$ & $0.00 \pm 0.00 \mathrm{c}$ \\
\hline
\end{tabular}

Means with different lowercase letters are significantly different (Tukey HSD at $P=0.05$ )
EPF are one of the bio-control agents that are recommended in IPM strategies (Feng et al. 2004). The talc-based formulation of beneficial microbes was found to be effective and cheap for pest and disease management in different crops (Saravanakumar et al. 2007). The fungal species against $C$. medinalis were documented earlier (Padmaja and Kaur 2001; Ambethgar et al. 2007; and Sivasundaram et al. 2007).

The difference of efficacy among the tested three fungi under controlled and greenhouse conditions may be due to environmental abiotic factors of temperature $\left({ }^{\circ} \mathrm{C}\right)$ and relative humidity $(\mathrm{RH})$, which influence the pathogenicity of fungi. High temperature reduces the germination of conidia and subsequently the efficacy of EPF (Sun et al. 2003). Ouedraogo et al. (1997) reported that $25^{\circ} \mathrm{C}$ was an optimum temperature for M. anisopliae. As well, the relative humidity affects the fungal growth as reported by Michalaki et al. (2006) that fungal growth is maximum at $51-74 \% \mathrm{RH}$.

\section{Conclusion}

EPF are among the alternative tools beside the chemicals for controlling C. medinalis. Recently, the studies, regarding EPF, have gained special considerations against insect pests. However, further studies are required to evaluate their efficacy and compatibility against $C$. medinalis under field conditions in various ecological zones of Pakistan.

Acknowledgements

The authors wish to thank AgriLife SOM Phytopharma (India) Limited (www.agrilife.in) for providing entomopathogenic fungi free of cost for experimental use.

Funding

No funding

Availability of data and materials

The datasets used and/or analyzed during the current study are available from the corresponding author on reasonable request.

\section{Authors' contributions}

$M R$ and BA designed the study and wrote the manuscript with input from all authors. AMS analyzed the data. MY and AQ read and approved the final manuscript. All authors read and approved the final manuscript.

Ethics approval and consent to participate Not applicable 


\section{Consent for publication}

Not applicable

\section{Competing interests}

The authors declare that they have no competing interests.

\section{Publisher's Note}

Springer Nature remains neutral with regard to jurisdictional claims in published maps and institutional affiliations.

\section{Author details}

${ }^{1}$ Rice Research Institute, Kala Shah Kaku, Punjab, Pakistan. ${ }^{2}$ Department of Biology, Government College for Women, Emanabad, Gujranwala, Pakistan. ${ }^{3}$ College of Earth \& Environmental Sciences, University of Punjab, Lahore, Pakistan

Received: 22 November 2018 Accepted: 8 February 2019

Published online: 26 February 2019

\section{References}

Alice J, Sujeeth RP, Nadarajan L (2003) Occurrence of entomopathogens fungi on rice pests on Karaikal region. Insect Environ 9(4):192

Ambethgar V (2003) Investigations on the development of mycoinsecticide formulations of an indigenous isolate of Beauveria bassiana (Bals.) Vuill. for the management of rice leaf folder, Cnaphalocrocis medinalis Guenee. Unpubl. Ph.D. Thesis, Tamil Nadu Agricultural University, Coimbatore, p 179

Ambethgar V, Swamiappan M, Rabindra RJ, Rabindran R (2007) Pathogenicity of certain indigenous isolates of entomopathogenic fungi against rice leaf folder, Cnaphaiocrocis medinalis (Guenee). J Biol Control 2(2):223-234

Ayala-Zermeňo MA, Gallou A, Am B-P, Serna-Dominguez MG, Arredondo-Bernal HC, Montesinos-Matias R (2015) Characterization of entomopathogenic fungi used in biological control programme of Diaphorina citri in Mexico. Biocontrol Sci Tech 25:1192-1207

Dal Bello GM, Fuse CB, Pedrini N, Padin SB (2018) Insecticidal efficacy of Beauveria bassiana, diatomaceous earth and fenitrothion against Rhyzopertha dominica and Tribolium castaneum on stored wheat. Int J Pest Manag 64:279-286

Feng MG, Pu XY, Ying SH, Wang YG (2004) Field trials of an oil based emulsifiable formulation of Beauveria bassiana conidia and low application rates of imidacloprid for control of false-eye leafhopper Empoasca vitis in southern China. Crop Prot 23:489-496

Fujiyoshi N, Noda M, Sakai H (1980) Simple mass rearing method of the grass leaf roller Cnaphalocrocis medinalis Guenee of young rice seedlings. Jpn J Appl Entomol Zool 24:194-196

Haider I, Akhter M, Sabir AM (2014) Evaluation of different insecticides against rice leaf folder Cnaphalocrocis medinalis (Guenee) under field conditions. Pak J Zool 46(5):1458-1461

Michalaki MP, Athanassiou CG, Kavallieratos NG, Batta YA, Balotis GN (2006) Effectiveness of Metarhizium anisopliae (Metshinkoff) Sorokin applied alone or in combination with diatomaceous earth against Tribolium confusum Du Val Larvae: influence of temperature, relative humidity and type of commodity. Crop Prot 25:418-425

Natarajan K, Ramaraju K (1997) Control of leaf folder under extreme weather conditions. Madras Agric J 66:252-254

Negasi A, Parker BL, Brownbridgc K (1998) Screening and bioassay of entomopathogenic fungi for control of silver-leaf whitefly Bemisia argentifolii. Insect Sci App 18:37-44

Ouedraogo A, Fargues J, Goettel MS, Lomer CJ (1997) Effect of temperature on vegetative growth among isolates of Metarhizium anisopliae and $M$. flavoviride. Mycopathol 137:37-43

Padmaja V, Kaur G (2001) Pathogenicity of Metarhizium anisopliae to rice leaf folder Cnaphalocrocis medinalis. J Biol Control 15:201-203

Prakash A, Rao J, Nandagopal V (2008) Future of botanical pesticides in rice, wheat pulses and vegetables pest management. J Biopest 1(2):154-169

Riasat T, Wakil W, Ashfaq M, Sahi ST (2011) Effect of Beauveria bassiana mixed with diatomaceous earth on mortality, mycosis and sporulation of Rhyzopertha dominica on stored wheat. Phytoparasitica 39:325-331

Saleem M, Ramzan M, Manzoor Z, Ali I (2004) Effect of various tillage practices on the population of hibernated stem borer larvae in rice-wheat cropping systems. J Anim PI Sci 14(1-2):14-15

Saravanakumar D, Muthumeena B, Lavanya N, Suresh S, Rajendran L, Raguchander T, Sammiyappan R (2007) Pseudomonas induced defence molecules in rice against leaf folder (Cnaphalocrocis medinalis). Pest Manag Sci 63:714-721

Sherawat SM, Inayat M, Ahmad T, Maqsood MK (2007) Determination of economic threshold levels (ETL) for the chemical control of rice stem borer. J Agric Res 45(1):55-59

Sivasundaram V, Rajendran L, Muthumeena K, Suresh S, Raguchander T, Samiyappan R (2007) Effect of talc-formulated entomopathogenic fungus Beauveria against leaf folder (Cnaphalocrocis medinalis) in rice. World J Microbiol Biotechnol 24:1123-1132

Sun J, Fuxa JR, Henderson G (2003) Effects of virulence, sporulation and temperature on Metarhizium anisopliae and Beauveria bassiana laboratory transmission in Coptotermes formosanus. J Invertebr Pathol 48:38-46

Tefera T, Pringle KL (2003) Effect of exposure method to Beauveria bassiana and conodia concentration on mortality, mycosis, and sporulation in cadavers of Chilo partellus (Lepidoptera: Pyralidae). J Invertebr Pathol 84:90-95

Ullah Ml, Arshad M, Abdullah A, Khalid S, Iftikhar Y, Zahid SMA (2018) Use of entomopathogenic fungi Beauveria bassiana (Hyphomycetes: Moniliales) and Isaria fumosorosae (Hypocreales: Cordycipitaceae) to control Diaphorina citri Kuwayama (Hemiptera: Lividae) under laboratory and semi-field conditions. Egypt J Biol Pest Control 28:75

\section{Submit your manuscript to a SpringerOpen ${ }^{\circ}$ journal and benefit from:}

- Convenient online submission

- Rigorous peer review

- Open access: articles freely available online

High visibility within the field

- Retaining the copyright to your article

Submit your next manuscript at $>$ springeropen.com 